\title{
Crustal 3-D geometry of the Kristineberg area (Sweden) with implications on VMS deposits
}

\author{
P. Skyttä ${ }^{1,2}$, T. Bauer ${ }^{1}$, T. Hermansson ${ }^{2}$, M. Dehghannejad ${ }^{3}$, C. Juhlin ${ }^{3}$, M. García Juanatey ${ }^{3}$, J. Hübert ${ }^{3}$, and \\ P. Weihed ${ }^{1}$ \\ ${ }^{1}$ Division of Geosciences and Environmental Engineering, Luleå University of Technology, 97187 Luleå, Sweden \\ ${ }^{2}$ Boliden Mineral AB, 93681 Boliden, Sweden \\ ${ }^{3}$ Uppsala University, Department of Earth Sciences, Villavägen 16, 75236 Uppsala, Sweden
}

Correspondence to: P. Skyttä (pietari.skytta@gmail.com)

Received: 28 September 2012 - Published in Solid Earth Discuss.: 8 October 2012

Revised: 16 September 2013 - Accepted: 27 September 2013 - Published: 31 October 2013

\begin{abstract}
Structural analysis of the Palaeoproterozoic volcanogenic massive sulfide (VMS) hosting Kristineberg area, Sweden, constrained by existing magnetotelluric (MT) and seismic reflection data, reveals that the complex geometry characterized by non-cylindrical antiformal structures is due to transpression along the termination of a major high-strain zone. Similar orientations of the host rock deformation fabrics and the VMS ore lenses indicate that the present-day geometry of the complex VMS deposits in the Kristineberg area may be attributed to tectonic transposition. The tectonic transposition was dominantly controlled by reverse shearing and related upright to overturned folding, with increasing contribution of strike-slip shearing and sub-horizontal flow towards greater crustal depths. Furthermore, the northerly dip of the previously recognized subsurface crustal reflector within the Kristineberg area is attributed to formation of crustal compartments with opposite polarities within the scale of the whole Skellefte district. The resulting structural framework of the main geological units is visualized in a 3D model which is available as a 3-D PDF document through the publication website.
\end{abstract}

\section{Introduction}

The Palaeoproterozoic Skellefte district (Fig. 1) in Sweden is one of the most important mining districts in northern Europe with numerous VMS (volcanogenic massive sulfide) deposits and a large potential for future discoveries. Structural evolution of the Skellefte district has recently been at- tributed to transpressional tectonics leading to the formation of structurally and metamorphically contrasting crustal domains with penetrative non-coaxial deformation at depth and more localized coaxial deformation higher-up in the crust (Bauer et al., 2011; Skyttä et al., 2012). Besides the orientation of the dominant structural elements, the form and attitude of the VMS deposits have been shown to be governed by the occurrence within either the non-coaxial or the coaxial domain (Bauer et al., under revision). In order to both increase the exploration potential and gain insight into the potential tectonic setting and the pre-tectonic 3-D form of the VMS deposits (e.g. Petersen et al., 2000; Yakubchuk, 2004), this paper aims at understanding (i) the complex 3-D structure of the Kristineberg area and (ii) the relationship between the recognized pattern of deformation partitioning and the tectonic transposition of the VMS deposits and the individual ore lenses occurring in the area.

The transition between the structurally contrasting domains within the central parts of the district is defined by a distinct high-strain zone (Skyttä et al., 2012) which has an apparent lateral continuation into the Kristineberg area (Fig. 1), but not through it further towards west. (Skyttä et al., 2010, 2012). The effects of the termination of this highstrain zone for the crustal 3-D geometry of the Kristineberg area are significant since much of the deformation within the Skellefte district has been shown to be controlled by highstrain zones (Allen et al., 1996; Bauer et al., 2011; Skyttä et al., 2012). Consequently, high-strain zones at various scales and their significance for partitioning of transpressional deformation is investigated and discussed in this paper. 


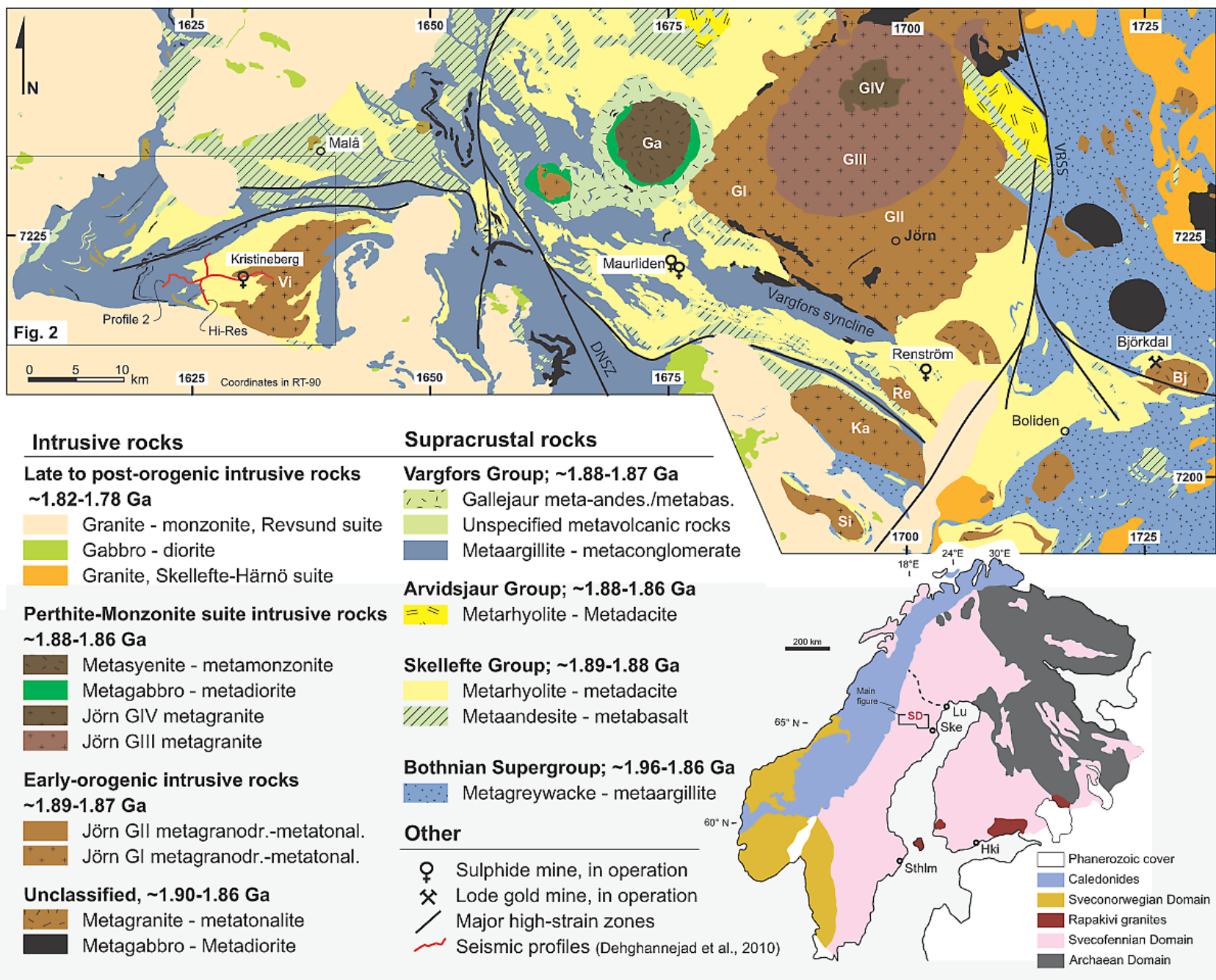

Fig. 1. Inset: generalized Fennoscandian Shield geology. Main map: geological overview of the Skellefte district, as loosely defined by the occurrence of the Skellefte Group metavolcanic rocks, and their immediate vicinity. DNSZ: Deppis-Näsliden shear zone; VRSS: VidselRöjnöret shear system. Intrusions: Bj: Björkliden, Ga: Gallejaur, Ka: Karsträsk, Re: Rengård, Si: Sikträsk, Vi: Viterliden, and GI, GII, GIII, GIV: Jörn-type intrusions, phases I-IV. Geology after Kathol et al. (2005) and Bergman Weihed (2001).

Due to the sparse occurrence of outcrops and complex crustal structure, a multidisciplinary approach comprising both geological and geophysical methods was required. Structural mapping and analysis aim at defining the geometry and kinematics of the main structures and tectonic history within the study area. Available magnetotelluric (MT) and seismic reflection data (Hübert et al., 2009; Dehghannejad et al., 2010, 2012b; García Juanatey et al., 2013) are used to constrain the in-depth continuation of the structures recognized from the surface, and to define a robust 3-D framework for the geological investigations ranging from regional to deposit scale. Correlations between the structural and geophysical data are first elaborated along 2-D sections whereas the final integration is done in three dimensions.
The results of the study are relevant to the understanding of transpressional processes in general. More specifically, the results contribute to ore geological research and exploration of Precambrian deposits, which characteristically occur in poorly outcropping areas devoid of stratigraphic marker horizons, and have been subjected to intense and polyphase deformation leading to significant modification of the original deposit geometries. More locally, the paper complements the recent structural and geophysical work done in the Skellefte district (e.g. Bauer et al., 2011; Dehghannejad et al., 2012a, b; García Juanatey et al., 2013; Skyttä et al., 2012) into an up-to-date geological synthesis.

This paper is supplemented by an interactive 3-D PDF model which may be downloaded through the publication website. 


\section{Geological and geophysical outline}

\subsection{Skellefte district}

The Skellefte district (Fig. 1) is an approximately $120 \mathrm{~km}$ by $30 \mathrm{~km}$ wide area loosely defined by the occurrence of the 1.89-1.88 Ga Skellefte Group metavolcanic rocks (Billström and Weihed, 1996; Montelius, 2005; Skyttä et al., 2011), which are the main host to the VMS deposits in the area (Allen et al., 1996). The Skellefte Group has been inferred to overlie the Bothnian Supergroup metasedimentary rocks (Rutland et al., 2001a, b; Skyttä et al., 2012). The dominantly metasedimentary 1.88-1.87 Ga Vargfors Group (Billtröm and Weihed, 1996) overlying the Skellefte Group, is the uppermost stratigraphical unit of the Skellefte district, and was coeval with the subaerial, predominantly volcanic Arvidsjaur Group which is present further to the north (Skiöld et al., 1993).

Intrusive rocks of the Skellefte district define two major periods of intrusive activity at approximately $1.89-1.86 \mathrm{Ga}$ and 1.82-1.78 Ga (Fig. 1; cf. Weihed et al., 2002; Gonzàles Roldán, 2010; Skyttä et al., 2011). The former period comprises the $1.89-1.87 \mathrm{Ga}$ early-orogenic, calc-alkaline granodiorites-tonalites and gabbros (Phases GI and GII of the Jörn intrusive complex), and the $1.88-1.86 \mathrm{Ma}$ alkaline granites-syenites-monzonites of the Perthite-monzonite suite (including Jörn GIII and GIV). The younger period comprises the $1.82-1.78 \mathrm{Ga}$ minimum melt S-type granites (Skellefte-Härnö suite), and the $1.80-1.78 \mathrm{Ga}$ coarseporphyritic, A- to I-type granites, monzonites and diorites (Revsund suite).

The structural evolution of the Skellefte district was largely controlled by a complex fault pattern that developed during early crustal extension (Allen et al., 1996; Bauer et al., 2011). The earliest tectonic deformation has been inferred at 1.89-1.87 Ga (Lundström et al., 1997, 1999; Lundström and Antal 2000, Rutland et al., 2001a, b) and was constrained to the deeper crustal levels, tentatively attributed to ductile crustal extension synchronous with the volcanism higher-up in the crust (Skyttä et al., 2012). The subsequent compressional deformation at $1.87 \mathrm{Ga}$ was characterized by coaxial deformation due to SSW-NNE shortening within the upper parts of the crust (Skyttä et al., 2012). In contrast, the deeper parts of the crust experienced non-coaxial higher-strain deformation under SSE-NNW transpressional conditions, either due to strain partitioning during the $1.87 \mathrm{Ga}$ event or due to a new compressional event at $1.86 \mathrm{Ga}$ (Skyttä et al., 2012). Mineral lineations within the upper, coaxial domain are steep to sub-vertical, and show significantly more gentle plunges within the lower, non-coaxial tectonic domain (Bauer et al., 2011; Skyttä et al., 2012). South-dipping reverse shear zones currently separate the above crustal domains in most parts of the Skellefte district (Dehghannejad et al., 2012a; Skyttä et al., 2012).
The youngest deformation phase at $1.82-1.80 \mathrm{Ga}$ (Weihed et al., 2002) has been attributed to approximately E$\mathrm{W}$ shortening, and was characterized by reverse shearing along steeply dipping, approximately N-S striking highstrain zones inferred originally as transfer faults generated under crustal extension (Bergman Weihed 2001; Bauer et al., 2011; Skyttä et al., 2012).

Metamorphic peak conditions reached partial melting in the south-eastern part of the district (Lundström et al., 1997), whereas sub-solidus PT-conditions at $\sim 3 \mathrm{kbars}$ and $\sim 600^{\circ} \mathrm{C}$ prevailed in the Kristineberg area (Kathol and Weihed, 2005). The metamorphic peak in the eastern and southern parts of the Skellefte district was associated with the oldest deformation event pre-dating the approximately $1.88 \mathrm{Ga}$ intrusions (Lundström et al., 1997, 1999). In the western and central parts of the district, the metamorphic peak was late- to post-tectonic with respect to the upright main folding, i.e. post-1.87 Ga (Årebäck et al., 2005; Skyttä et al., 2012). Most of the crustal evolution models suggest that the Skellefte district is a remnant of a volcanic arc accreted towards the Karelian craton in the NE (Weihed et al., 2002). However, the subduction-zone configurations show significant variations (e.g. Hietanen, 1975; Gaál, 1990; Juhlin et al., 2002).

\subsection{Kristineberg area}

The supracrustal rocks of the Kristineberg area define the regional-scale Kristineberg antiform which encloses two individual second-order west-plunging antiforms: the Southern antiform cored by the $1.89 \mathrm{Ga}$ Viterliden intrusion (Skyttä et al., 2011), and the Northern antiform by the Skellefte Group metavolcanic rocks (Fig. 2a). The antiforms are separated by either a synform (Årebäck et al., 2005) or a major shear zone (Malehmir et al., 2007; Dehghannejad et al., 2010) occurring within the Vargfors Group metasedimentary rocks. Strain within the Kristineberg area was heterogeneously distributed with strong partitioning into curviplanar E-W to NE-SW striking high-strain zones with low-strain tectonic lenses in between (Skyttä et al., 2010). The high-strain zones are not penetrative but die out against the reclined hinge of the Kristineberg antiform hinge in the west (Fig. 2a; Skyttä et al., 2009). Gently-plunging lineations within the Viterliden intrusion have been attributed to sub-horizontal crustal flow which occurs also outside the high-strain zones (Skyttä et al., 2010). The dip-slip and dextral strike-slip deformation along the $\mathrm{E}-\mathrm{W}$ shear zones have been attributed to an overall SSE-NNW transpressional tectonic regime within the deeper crustal domain (Skyttä et al., 2012).

Two mineralized horizons occur in the Kristineberg area: the upper one comprises the Rävliden, Rävlidmyran and Hornträsk deposits and is located in a typical setting for the Skellefte district VMS deposits, close to the upper part of the Skellefte Group stratigraphy (Fig. 2a; Allen et al., 1996; Årebäck et al., 2005). The stratigraphically lower 

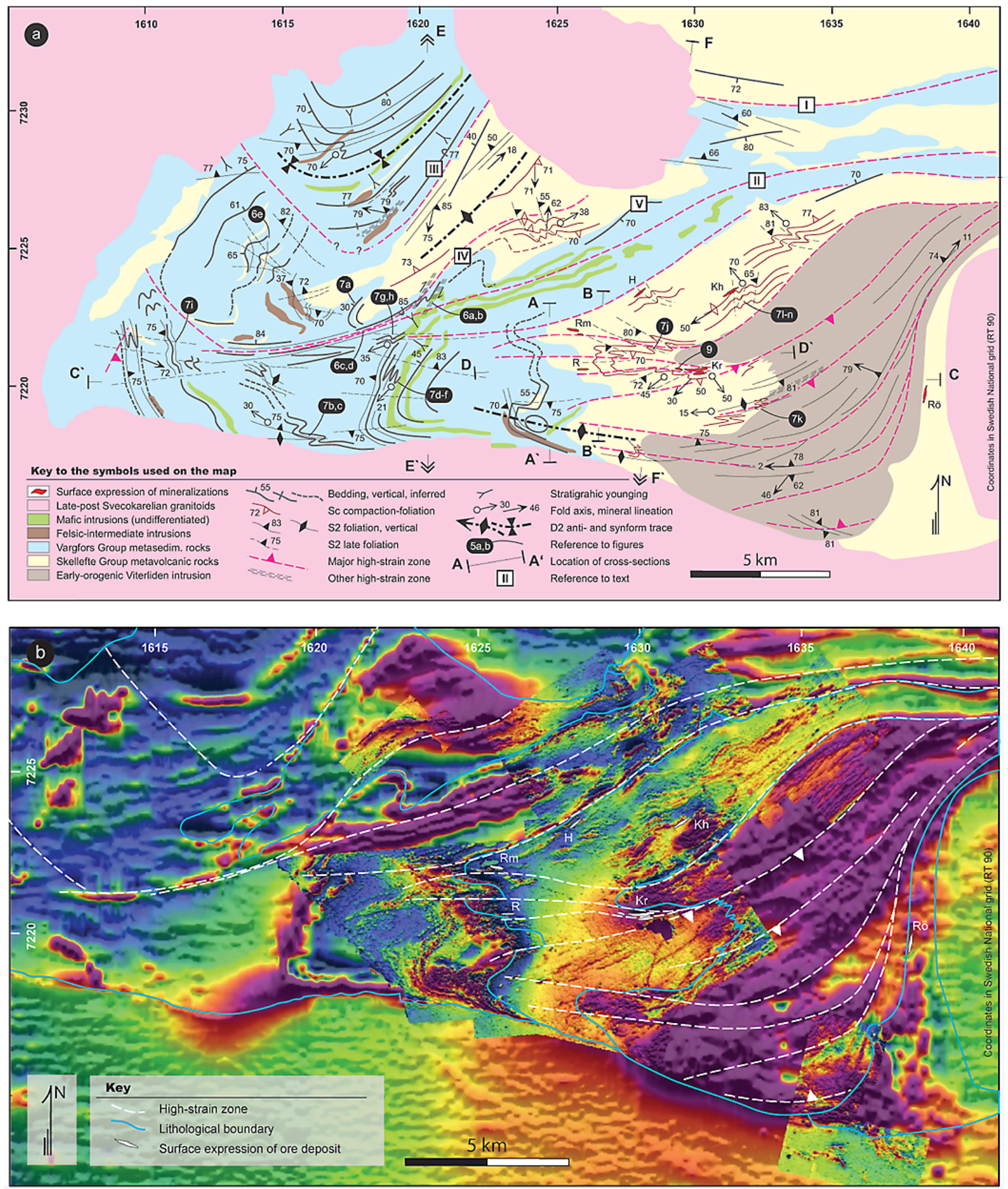

Fig. 2. (a) Kristineberg area geology. Modified after Kathol et al. (2005) and Skyttä et al. (2009, 2010), with new structural data from 249 localities visited during the course of the work. The "Northern and Southern antiforms" cited in the text are located to the north and south of the high-strain zone "II". "Hi-Res" and "Profile 2" in Fig. 4c and d (Dehghannejad et al., 2010) are located along cross sections B-B" and D-D', respectively. E-E' and F-F" indicate the locations for "Profile 5" and "Profile 1" in Fig. 4a and b (Tryggvason et al., 2006); notice that "Profiles 1 and 5" extend beyond the area of this figure. Geological cross sections A-A', B-B' and C-C' are shown in Fig. 5. Ore deposits: H: Hornträskviken, Kh: Kimheden, Kr: Kristineberg, R: Rävliden, Rm: Rävlidmyran, Rö: Rökå. (b) Total magnetic map of the Kriberg area (aeromagnetic covering the whole figure, source SGU; ground magnetic map for the central parts, source Boliden Mineral AB). Notice that the extent of (b) is smaller than that of (a). 
horizon includes the Kristineberg and Kimheden deposits. The $1889 \pm 3$ Ma minimum age for the ore deposition and volcanism inferred for the deeper parts of the Skellefte Group stratigraphic succession implies that volcanism may have started prior to the emplacement of the Viterliden intrusion at around $1890 \mathrm{Ma}$ (Skyttä et al., 2011). On the other hand, the $1883 \pm 6 \mathrm{Ma}$ age for the Kristineberg hanging-wall rhyolite (Skyttä et al., 2011) infers that at least part of the Skellefte Group post-dates the Viterliden intrusion, thus being in contradiction with a model attributing the generation of VMS deposits to heat influx from emplacement of the Viterliden intrusion into the volcanic pile (Galley and Bailes, 1999).

The present-day Kristineberg deposit geometry (Fig. 3) has been attributed to synvolcanic stratiform sub-seafloor sulfide replacement later followed by tectonic deformation leading to transposition of the main parts of the lenses into moderate to steep southerly dips, and stacking and folding of their present-day deeper parts (e.g. the J lens; Årebäck et al., 2005). Årebäck et al. (2005) considered the absence of remobilization of A and B lenses, as well as contrasting precursor compositions of the flanking volcanic units indicative of the presence of two separate sulfide sheets prior to deformation. Hence, the model disagrees with the geometrical model of tectonically stacked sheet by Jolley (2001), but agrees with its kinematic interpretation attributing the deformation to reverse south-dipping shear zones. Reverse shearing was considered responsible for folding of the $\mathrm{J}$ lens and, consequently, the major change in the deposit geometry at approximately the $1000 \mathrm{~m}$ level was attributed to the occurrence of a synform core south of the A and B lenses (Årebäck et al., 2005). Skyttä et al. (2009) suggested that localized sub-horizontal flow below the $1000 \mathrm{~m}$ level in the mine could have contributed to the change in the deposit's shape. The Rävliden and Rävlidmyran deposits (Fig. 2a) occur as several elongated lenses defining sub-vertical dips and gentle westerly plunges close to Skellefte Group-Vargfors Group contact.

\subsection{Seismic reflection}

The seismic reflection data in the Kristineberg area consists of approximately $70 \mathrm{~km}$ of seismic lines that have been recorded along four profiles, reaching depths of 4-12 km (Tryggvason et al., 2006; Malehmir et al., 2007, 2009a, b; Dehghannejad et al., 2010, 2012a; Ehsan et al., 2012). The main outcome of the two first $\mathrm{N}-\mathrm{S}$ trending profiles with $25 \mathrm{~m}$ source-receiver spacing are north dipping reflections which cannot be traced to the surface, but have been interpreted to represent a major shear zone occurring between the Skellefte Group metavolcanic rocks and the underlying Bothnian Supergroup metasedimentary rocks (Fig. 4a, b; Tryggvason et al., 2006; Malehmir et al., 2007). Further investigations including the "high-resolution" profile with $10 \mathrm{~m}$ source-receiver spacing have revealed a series of steeply south-dipping to sub-horizontal reflections (Fig. 4c;

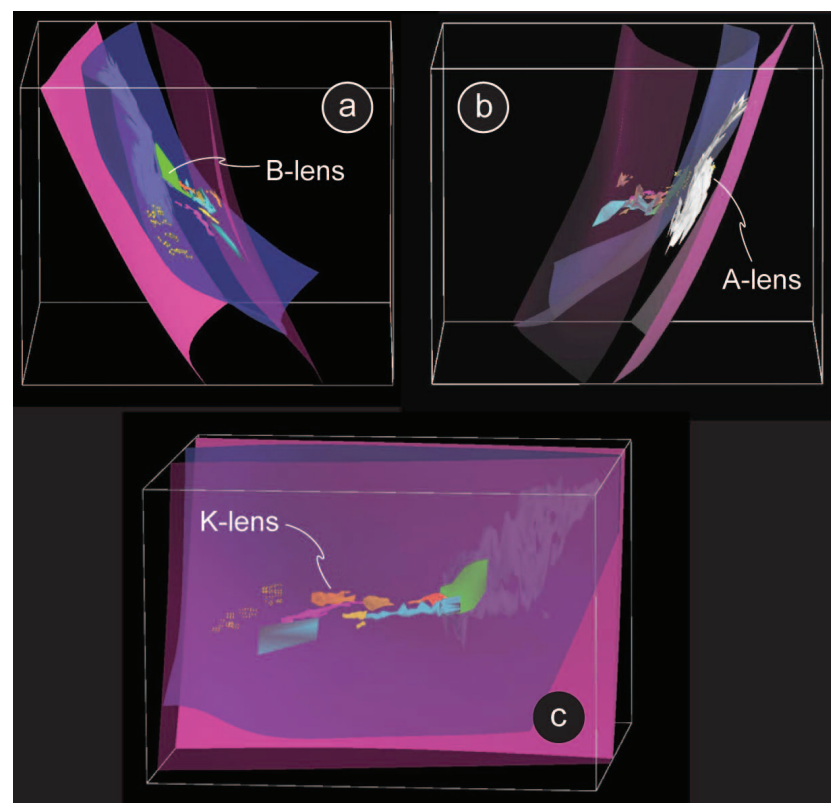

Fig. 3. gOcad screenshots illustrating the geometry of the Kristineberg deposit VMS lenses. (a) Cross-sectional view towards east. (b) Cross-sectional view towards west. (c) Longitudinal view towards north. Selected high-strain zones are shown for reference in different shades of magenta (see "Supplement" for details). Height of the bounding boxes are $2.5 \mathrm{~km}$.

Dehghannejad et al., 2010, 2012b). Part of these reflections could be correlated with known or inferred geological features, e.g. the Kristineberg "ore horizon" and the contact between the Skellefte Group and Vargfors Group rocks ("M1" and "C1" in Fig. 4c, respectively; Dehghannejad et al., 2010, $2012 b)$. In contrast, other reflections have been attributed to more gently-dipping features, possibly ore-bearing horizons at depth (Fig. 4c; Dehghannejad et al., 2010). Furthermore, the E-W long-sectional profile (Fig. 4d) shows gently WNWdipping reflections, interpreted as shear zones transecting the eastern part of the Viterliden intrusion (Dehghannejad et al., 2010). The overall westerly inclination of structures is imaged by the gently west-dipping contact of the SkellefteVargfors Group contact in the hinge of the Southern antiform ("N1" in Fig. 4d, see also Fig. 2a).

\subsection{Magnetotelluric data}

In the Kristineberg area, MT data has been collected from 70 broadband stations located mainly along the seismic profiles (Garcia Juanatey et al., 2012). Two of the three analyzed and inverted 2-D MT profiles, with constraints from seismic reflection studies (Hübert et al., 2009, and García Juanatey et al., 2013) have been used in this investigation.

The resistivity contrasts observed in the MT models (Fig. 4e, f) allow recognition of several geological features known from surface geology and seismics. These include 

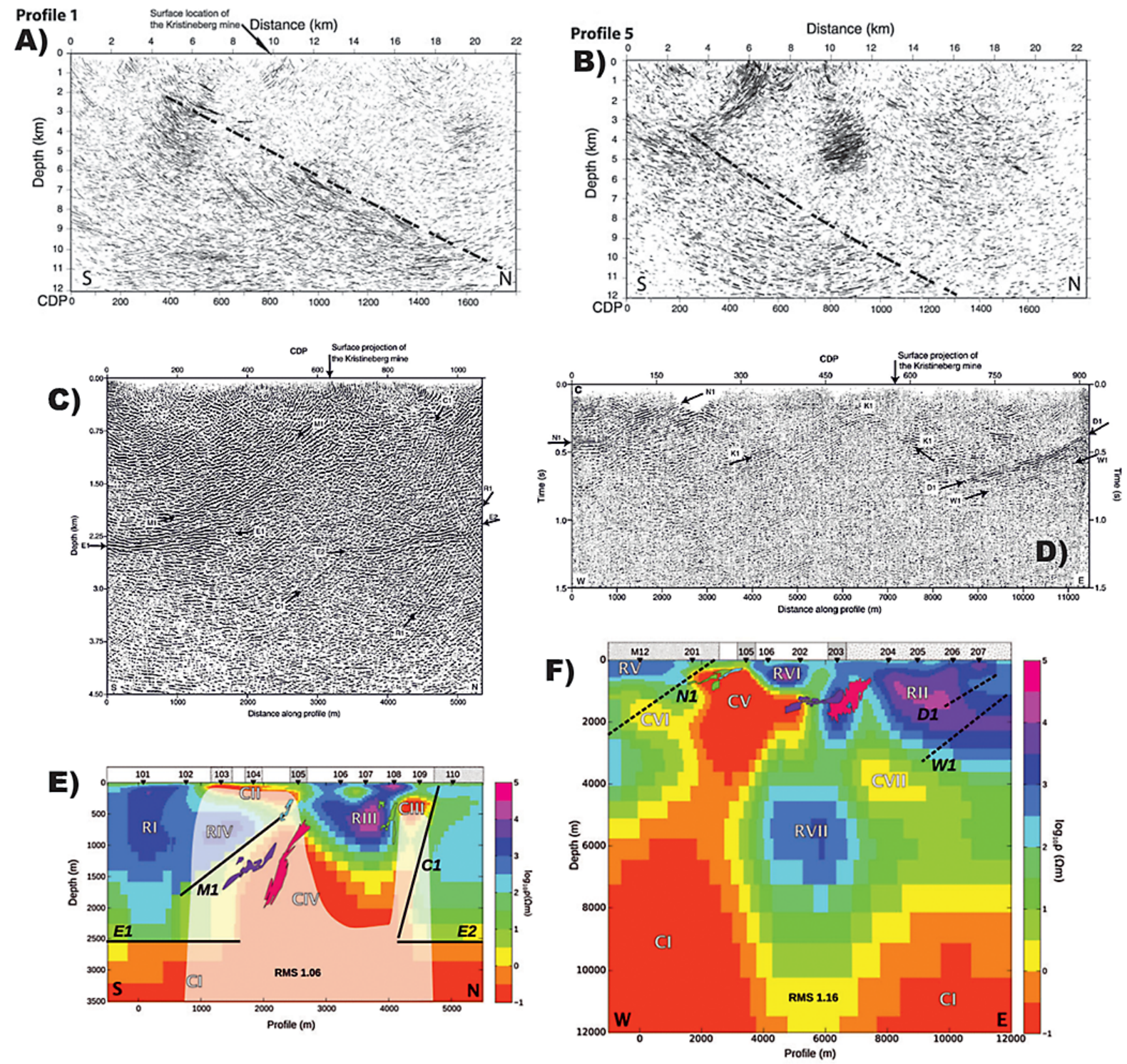

Fig. 4. Existing seismic reflection and MT profiles from the Kristineberg area, see Fig. 2a for locations. (a) and (b) Profiles 1 and 5 from Tryggvason et al. (2006). (c) and (d) high-resolution and Profile 2 from Dehghannejad et al. (2010). (e) and (f) MT profiles from García Juanatey et al. (2013); the black lines refer to seismic reflectors in (c) and (d).

conductive graphitic shales along the Skellefte-Vargfors Group contact ("CII" in Fig. 4e), resistors "RI", RIII", "RVI" which have been interpreted as Skellefte Group volcanic rocks, and which are bound in the depth by conductors "CIV" and "CV". Furthermore, conductors "CIII", CIV" and "CV" are interpreted to represent hydrothermally altered rocks within the "ore horizons" (García Juanatey et al., 2013). Particularly good correlation between the know geometry of the VMS ore and the MT results exists e.g. along the top contact of conductor "CV" and the deepest parts of the Kristineberg ore (Fig. 4f). For this reason, the method has proven potential in constraining the extent of the ore at least indirectly by imaging the distinct geophysical signatures of the host- ing rock packages (García Juanatey et al., 2013; Hübert et al., 2009, 2013). The MT data also allows recognition of the late-orogenic granites and other intrusions (resistors), and the orientation of the previously recognized deep conductor has been refined to have a north-easterly dip (García Juanatey et al., 2013).

\section{Methodology}

\subsection{Structural geology}

Geological mapping was carried out in an approximately 15 by $30 \mathrm{~km}$ area, within the supracrustal rocks occurring in 
the Kristineberg antiform (Fig. 2a). The structural observations in the field, complemented by microstructural studies from thin sections, aimed specifically at (i) understanding the development of metamorphic foliations, (ii) delineating the orientation and orientation distribution of mineral lineations, and (iii) determining the sense of shear from major high-strain zones. These constraints were later used in determining the relative timing of deformation events and in characterising the kinematic evolution of the crust. Spatially, the observations had both a local-scale focus in the Kristineberg deposit vicinity and a more regional focus along the contacts of the main lithological units. In addition to the field observations, we used airborne and ground magnetic maps in delineating the major shear zones and contacts between the geological units (Fig. 2b). Structures within the Kristineberg mine vicinity were summarized from geological profiles compiled from drillings by Boliden Mineral AB and by detailed mapping of the surface expression of the north-western part of the deposit (A4 open pit). Recent structural data from the Viterliden intrusion (Skyttä et al., 2010) complements the data set presented in this paper and, together with a more regional overview (Skyttä et al., 2012), allows making a comprehensive structural synthesis of the Kristineberg area.

\subsection{3-D modelling}

Structural and geophysical data described in the previous chapters was integrated into geological cross sections (Fig. 5) which, together with the 3-D constraints from the structures, MT and seismic data, served as the nucleus for the 3-D modelling. Other source data comprises surface geology observations, aeromagnetic maps (the Geological Survey of Sweden, SGU), logs of selected drill holes transecting significant lithological contacts, ground magnetic data, geological cross sections, plan views, ore lens 3-D geometries and near-mine 3-D models from Boliden Mineral AB. The gOcad software platform (Paradigm), supported by the Sparse plug-in (Mira Geosciences), and the MOVE ${ }^{\mathrm{TM}}$ software (Midland Valley Exploration Ltd.) were used in model building. The workflow included the integration of point, section and map data into 3-D surfaces. No numerical modelling has been involved.

\section{Structural analysis}

\subsection{Overview}

The Kristineberg antiform encloses two second-order antiformal structures, the Southern and Northern antiforms representing the deeper and the upper crustal domains, respectively (Fig. 2a). The structural characteristics of the domains are listed in Table 1 and the structural measurements are presented in Fig. 8. The data description follows thematic subdivision into high-strain zones, tectonic lenses in-between and detailed structural observations from the Kristineberg A4 open pit. Assigning the observed structures into separate deformation phases becomes possible only after the structural analysis and interpretation, but the labels are already used in the data presentation (Figs. 2a, 6, 7, 9) to avoid unnecessary repetition and to make the paper easier to follow.

Characteristic for the whole Kristineberg area are highstrain zones which typically occur along the steep to overturned antiform limbs, but also as axial surface parallel to these folds (Figs. 2a, 5). The high-strain zones are typically curviplanar and strike NE-SW to E-W, except for two SENW striking high-strain zones in the north-western part of the study area. The high-strain zones are associated with development of shear fabrics, as well as a variable degree of tectonic transposition of supracrustal units and primary geological contacts (Figs. 2a, 5). All the high-strain zones die out before reaching the hinge of the Kristineberg antiform in the west.

\subsection{Structural data set}

Components of both dextral strike-slip deformation (Fig. 6a, b) and reverse dip-slip deformation (Fig. 6c, d) were observed along a high-strain zone separating the Southern and Northern antiforms (Fig. 2a). The dip-slip deformation occurred under both ductile and brittle-ductile conditions (Fig. 6c, d). En-echelon patterns of quartz veins locally indicate sinistral strike-slip deformation along the layer boundaries in the western part of the study area (Fig. 6e).

While the high-strain zones are typically accompanied with asymmetric folds overturned to the north, structures within the tectonic lenses between the high-strain zones range from variably dipping primary depositional contacts (Fig. 7a, b; "V" in Fig. 2a) to open upright folds with approximately E-W axial surfaces (Fig. 7c) to tight folds with steep $\mathrm{N}-\mathrm{S}$ to SW-NE striking axial surfaces (Fig. 7d-h). Except for local overturning in the vicinity of the high-strain zones, sedimentary younging directions are indicative of right-wayup attitude for the sedimentary succession. The folds with $\mathrm{N}-$ $\mathrm{S}$ to SW-NE striking axial surfaces and the related deformation fabrics within the metasedimentary rocks are overprinted by more localized fabrics (Fig. 7d-h), which locally show a spatial relationship with minor semi-brittle E-W shear zones (Fig. 7i). The foliation of an apparently older generation occurs frequently also without any associated fold structures (S2 in Fig. 6e). Overprinting relations similar to those within the metasedimentary rocks may be found also within the altered Skellefte Group metavolcanic rocks, where isoclinally folded foliations, sub-parallel with the primary bedding, are obliquely cross-cut by later crenulations (Fig. 7j). The late crenulations define an intensely fanning pattern with strikes ranging from approximately E-W to N-S (the Southern antiform area; Figs. 2a, 7f, k), and vary from semi-penetrative (Fig. 7j) to brittle and spaced (Fig. 7k) in nature. The earliest foliations have been preserved either as inclusion trails in chlorite porphyroblasts (Fig. 71) or in hinges of rootless 
Table 1. Summary of the tectonic domains and their characteristic structural features.

\begin{tabular}{lll}
\hline Crustal domain & Upper domain & Lower domain \\
\hline Dominant deformation style & Coaxial & Non-coaxial \\
Bulk compression orientation & SE-NW & SE-NW \\
Dominant high-strain zone orientation & SW-NE to WSW-ENE & E-W (SW-NE in the Viterliden intrusion) \\
High-strain zones kinematics & Dip-slip along high-strain zones & Dip-slip + dextral strike-slip along high-strain zones \\
Lineation pattern & Steep to vertical in both shear zones & Steep (dominant) + sub-horizontal in high-strain \\
& and tectonic lenses in-between & zones, moderate to sub-horizontal in tectonic \\
& & lenses between the high-strain zones \\
\hline
\end{tabular}

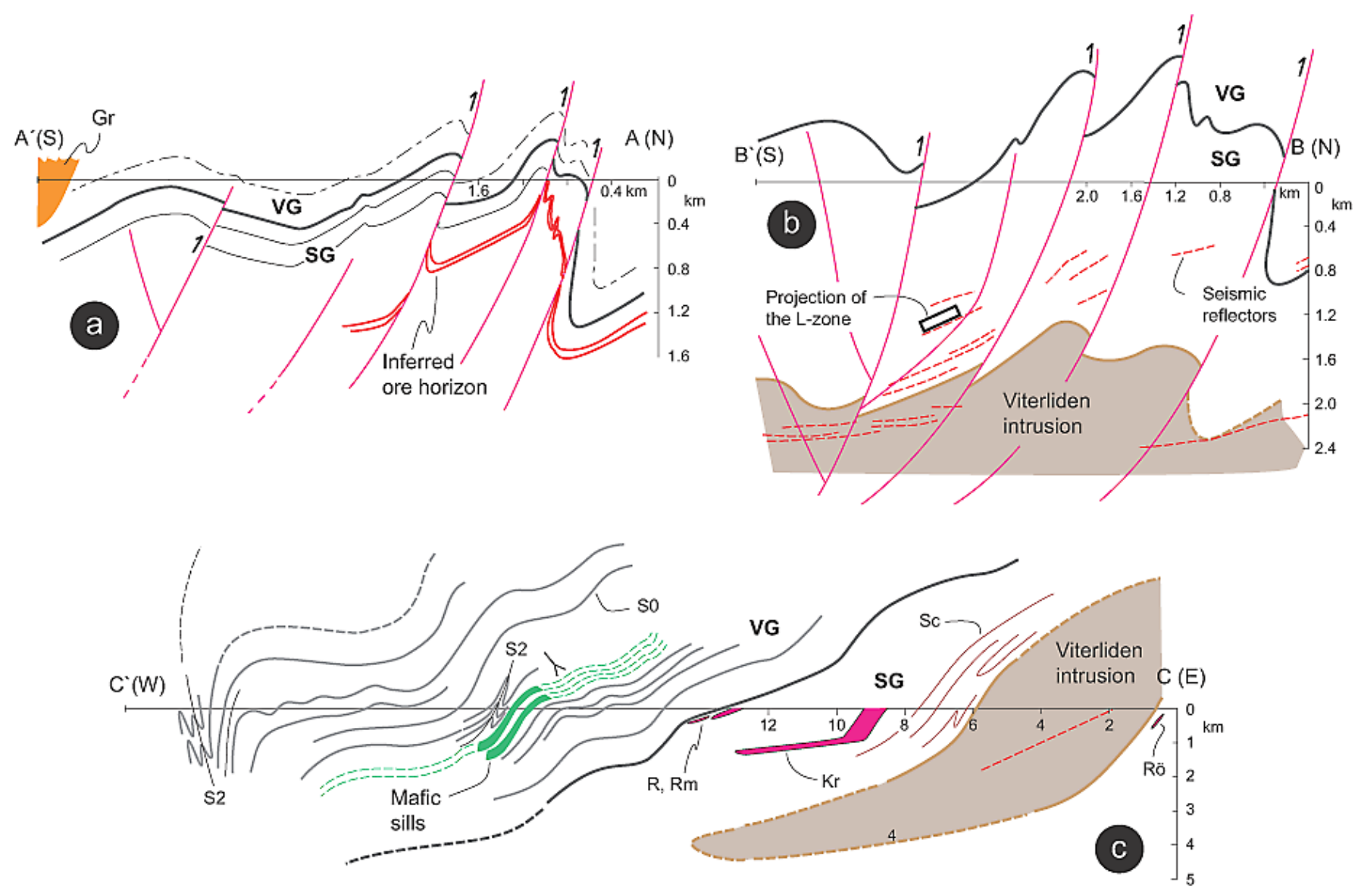

Fig. 5. Geological cross sections, see Fig. 2a for location. (a) Cross section through the contact zone between the metavolcanic and metasedimentary rocks, Gr: late-orogenic granite, SG: Skellefte Group, VG: Vargfors Group, (b) Cross section along the "high-resolution" seismic profile in Fig. 4c (Dehghannejad et al., 2010). (c) Longitudinal E-W cross section. The section is parallel to the E-W seismic line in Fig. 4d but extends further both towards $\mathrm{E}$ and W. Abbreviations for ore deposits as in Fig. 2a.

isoclinal intrafolial folds (Fig. $7 \mathrm{~m}, \mathrm{n}$ ). In contrast to the intensely altered metavolcanic rocks, only one foliation could be found in the less-altered metavolcanic rocks, e.g. in the Northern antiform (Fig. 2a).

Mineral lineations scatter along a vertical SW-NE girdle with sub-vertical and steeply-plunging lineations dominant in the upper crustal domain (Fig. 8a, b). In contrast, the lower crustal domain additionally displays several sub-horizontal lineations and a cluster of moderately SW-plunging lin- eations, the latter spatially occurring around and to the southwest of the Kristineberg deposit (Figs. 2a, 8b). The tectonic foliations within both crustal domains have approximately the same orientations (Fig. 8c, d). The distribution of bedding surfaces and fold axes on the stereoplots reflects the complex, non-cylindrical fold structure in both domains (Fig. 8e-h).

The A4 open pit exposes the western continuation of the Kristineberg deposit A-lens (Figs. 2a, 9a). The excavated VMS ore occurred as an approximately $10 \mathrm{~m}$ thick sheet 

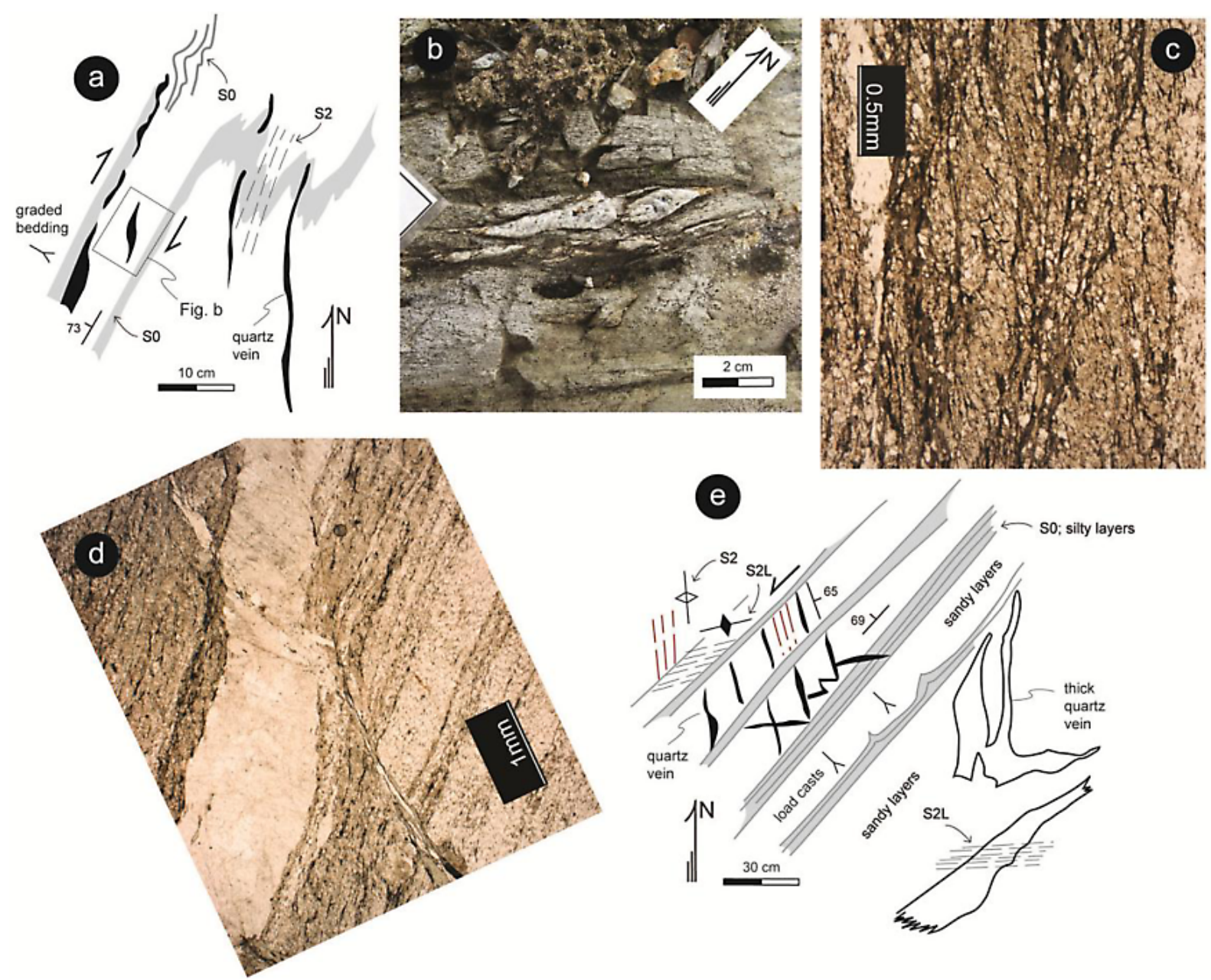

Fig. 6. Shear zone kinematics and fabrics. (a) Outcrop sketch illustrating the folding and shearing along the high-strain zone occurring along the southern limb of the Northern antiform. (b) Lensoidal quartz vein with asymmetric wings indicative of dextral shear. (c) Ductile north-side-up dip-slip movement recorded in metasedimentary rocks occurring along a major sub-vertical high-strain zone. Vertical section, view towards ENE. (d) A semi-brittle reverse, south-side-up shear band deforming the sub-vertical foliation and parallel quartz veins, same outcrop as in (c). Vertical section, view towards ENE. (e) Outcrop sketch illustrating the en-echelon pattern of quartz veins occurring within thicker sandy units, between laminated silty units, in a metasedimentary succession on the north-west limb of the regional Kristineberg antiform.

parallel with the host rock foliation, striking WNW-ESE and dipping moderately towards SSW (Fig. 9a). Folds deforming the main foliation on both sides of the ore sheet have parallel axes, and are further parallel with the moderately SWplunging mineral lineation, but vary in the attitude of the axial surface. Axial surfaces of the tight folds in the sericitealtered metavolcanic rocks in the stratigraphic hanging wall to the ore dip moderately towards the west (Fig. 9b). In the footwall, the axial surfaces in the stockwork mineralization dip steeply towards south-east (Fig. 9c) and the fold shape progresses from gentle-open in the east to tight-isoclinal in the west (Fig. 9a). Furthermore, the ore shows local transposition and detachment from the main lens along the axial surface of the folds in the area of the most intense folding. In the western part of the pit, the ore shows an apparent dextral deflection into a steeply west-dipping, NNE-SSW striking high-strain zone which constrains the western extent of the ore (Fig. 9d). The eastern extremity of the ore is not exposed.

Geophysical signatures of the Rökå mineralization east of the Viterliden intrusion (Fig. 2a) infer moderate westerly dips (Boliden Mineral AB; unpublished exploration report). The Hornträsk and Kimheden deposits occurring along the northern limb of the Southern antiform have gentle to moderate plunges towards WSW. 


\subsection{Interpretation}

\subsubsection{Framework of major deformation zones and structural domains}

The geological and the high-resolution seismic reflection data (Dehghannejad et al., 2010) indicate that the high-strain zones in the vicinity of the Kristineberg mine and to the west of it have southerly dips down to approximately $2 \mathrm{~km}$ below the ground level (Fig. 5). Extrapolation of their extent at depths greater than this is constrained by other geophysical data and discussed in Sect. 6.

The major structural change across an E-W striking shear zone in the northern part of the Kristineberg area ("I" in Fig. 2a), from approximately E-W trending low-strain structures in the north (Lickorish, 2005) to more complex structural signatures in the south, indicates that the area to the south of the high-strain zone, i.e. the whole Kristineberg area, occurs in the SSE-NNW transpressional lower crustal domain as defined by Skyttä et al. (2012). However, the Kristineberg area may be further divided into a coaxial domain (the Northern antiform), and a transpressional domain (the Southern antiform). Characteristic for the coaxial domain are the upright folds with a SW-NE axial surface strike and local occurrence of minor dextral and sinistral shear zones (Fig. 6a, b, e). In contrast, the larger structural versatility and, in specific, development of dextral strike-slip zones characterizes the non-coaxial Southern antiform. As a consequence, we infer that there is a major dip-slip dominated high-strain zone (Fig. 6c, d) located between the Northern and Southern antiforms ("II" in Fig. 2a). Interaction between the Southern and Northern antiforms west of the E-W highstrain zone terminations explains the complex structural geometry of the western hinge area of the regional Kristineberg antiform (Fig. 2a).

Within the upper crustal coaxial domain, the overturning of bedding planes north-west of the contact with the metasedimentary rocks ("III" in Fig. 2a) suggests that the contact is defined by an inverted normal fault (cf. Bauer et al., 2011). Furthermore, the parasitic synclinal fold on the southern limb of the Northern antiform is attributed to deformation along the shear zone at "IV" in Fig. 2a, whereas the contact at "V" is of primary sedimentary nature.

\subsubsection{Deformation chronology}

The main foliation within the Vargfors Group metasedimentary rocks occurs along the axial surfaces of upright folds (Fig. 7b, c), hence allowing a district-scale correlation with the main fabric of the upper crustal domain of Skyttä et al. (2012). Consequently, the fabric is labelled S2. Since the earliest fabric of the Skellefte Group rocks (Figs. 7j, k, 9b, c) occurs sub-parallel with the primary bedding, is only locally associated with early folds within the mechanically weak, intensely altered rocks, and experienced a similar tectonic overprinting with the metasedimentary rocks, we attribute the early fabric to gravitational compaction within a pile of altered (meta)volcanic rocks. Consequently, the fabric is labelled Sc, and may regionally be correlated with $\mathrm{S} 1$ by Allen et al. (1996) and "compaction-related foliation" by Skyttä et al. (2012). Strike of the axial surfaces and fold axes of the ductile folds (F2) vary significantly (Figs. 2a, 8g, h), but the overprinting relation (Fig. 7d, i-k) confirms that the folds are of the same generation.

The spaced crenulations overprinting D2 fabrics have EW strikes along the low-strain hinge of the Southern antiform (Fig. 7d surroundings). In contrast, within the metavolcanic units close to the Kristineberg and Kimheden deposits, the crenulations show fanning patterns and non-planar geometries (Fig. 2a). Despite the locally scattering orientations, the dominant approximately E-W strike suggests that this event took place at a late stage of D2 rather than the regional D3 attributed to E-W shortening (Bergman Weihed, 2001). Consequently, we label the fabric S2L ("late-S2"). The variations and the more north-southerly strikes of S2L north of the Kimheden deposit are attributed to late-D2 shearing within incompetent altered metavolcanic rocks. Although the S2L fabric has a widespread occurrence, the D2L event is considered insignificant as defining the regional structural geometries.

\subsubsection{Deformation geometry and kinematics}

Taken that any folds deviating from the characteristic E-W orientation occur predominantly along N-S to NE-SW striking lithological contacts, we infer that the orientation is not due to timing, but strain partitioning. For this reason, we attribute the development of contrasting structural orientations during D2 to SSE-NNW transpression. The "normal" transposition of strata into E-W striking, steeply-dipping to overturned attitudes took place along high-strain zones parallel with E-W striking axial surface of the antiform (Figs. 2a, $5 \mathrm{a}, \mathrm{b}$ ), and accommodated the $\mathrm{N}-\mathrm{S}$ shortening component of transpression. Between the E-W striking high-strain zones, localized development of steeply west to north-west dipping domains (Fig. 7d, e) is attributed to the E-W shortening component of transpression. The localization of the E-W component of transpression is inferred to have nucleated along contacts of rheologically contrasting lithologies when transpressional deformation caused pronounced uplift in the eastern part of the Kristineberg area, eventually leading to the westplunging orientation of the Southern antiform. As a result, a zonal "flat-steep-flat" pattern characterized by alternating gentle and steep westerly dips was developed (Fig. 5c). Consequently, the regional-scale fold geometry of the Southern antiform is strongly non-cylindrical with the largest deviation from the gentle westerly plunge within the western reclined hinge of the Kristineberg antiform (Figs. 2, 5c, 8h).

As a consequence of the synchronously acting E-W and $\mathrm{N}-\mathrm{S}$ compression within the SSE-NNW transpressional 

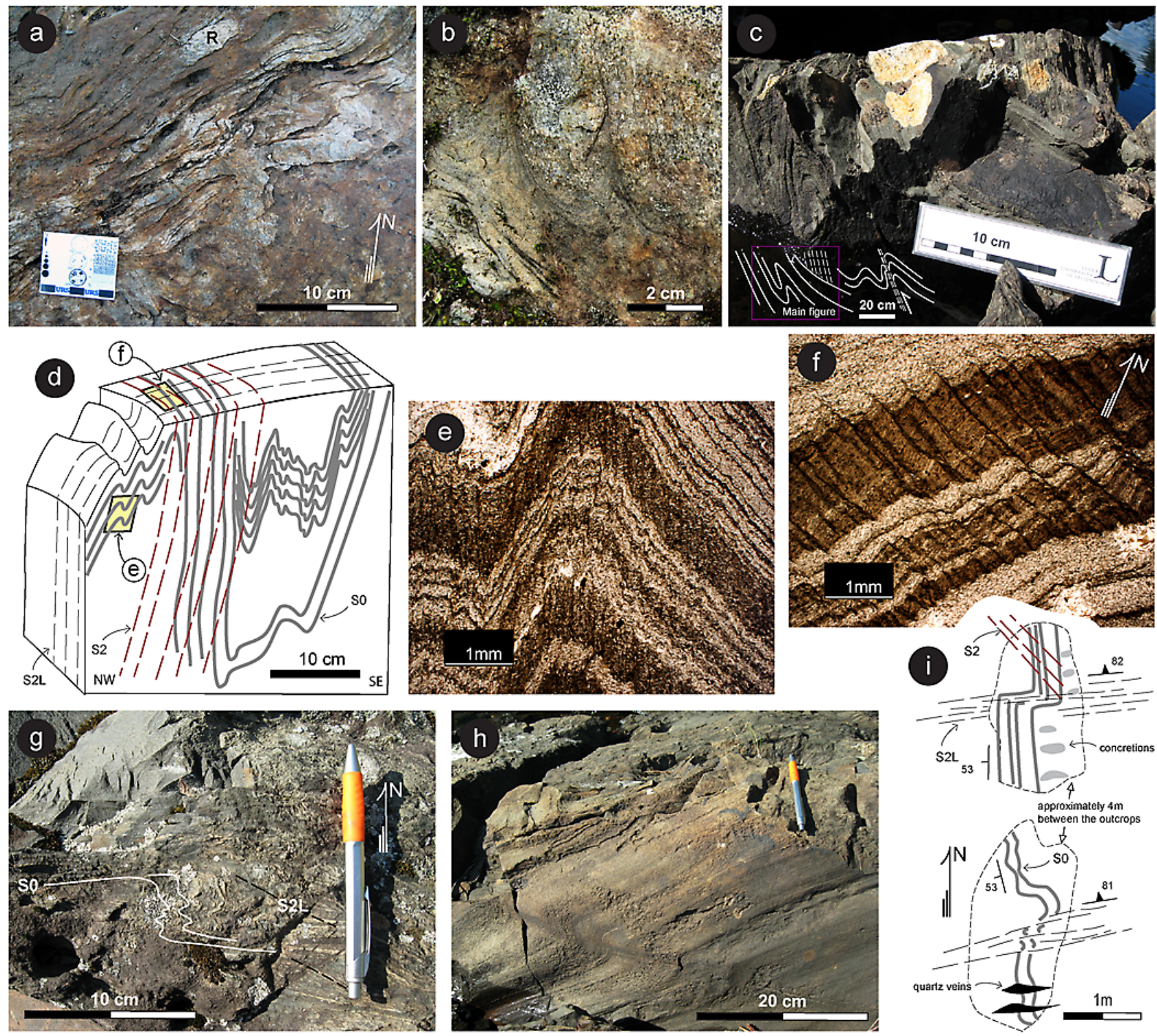

Fig. 7. Folds and fabrics within the metasedimentary $(\mathbf{a}-\mathbf{i})$ and metavolcanic $(\mathbf{j}-\mathbf{n})$ rocks. Distinction between the structures of successive generations is elaborated in Sect. 4.3.2. However, the final labels for the structures are used in the maps to allow better readability. (a) Contact between the Skellefte Group felsic volcanic rock (bottom) and the Vargfors Group metasedimentary rocks (top). Notice the volcanic rip-off clast $(\mathrm{R})$ in the metasedimentary rock. (b) Load casts indicating stratigraphic younging upwards in metasedimentary rocks with subhorizontal bedding surfaces cross-cut by sub-vertical S2 foliation. Vertical section, view towards NW. (c) Cylindrical F2 folds overturned towards south. The inset illustrates the parallel attitude of local reverse shear zones and the S2 foliation. Vertical section, view towards WNW. (d) Field sketch of upright, ductile F2 folds overprinted by spaced S2L foliation. (e) S2 foliation developed along the axial surface of an upright F2 fold, see (d) for location. Vertical section, view towards NE. (f) Asymmetric, spaced S2L crenulation cleavage deforms bedding and the sub-parallel S2 foliation. (g) Asymmetric z-shaped F2-folds overprinted by S2L crenulation cleavage in a micaceous domain of the metasedimentary rocks. (h) S-shaped F2L-folds developed in a sandy unit of a metasedimentary succession. Vertical section, view towards NNW. (i) Stratified metasedimentary rocks displaying a weak oblique S2 foliation, subsequently overprinted by distinct D2L-shear zones, associated with the development of S2L shear foliation, transposition of concretions, and syntectonic quartz veining. (j) D2l-crenulations overprinting isoclinal F2 folds. (k) Composite crenulation and solution cleavage surfaces deforming altered metavolcanic rocks close to the western contact of the Viterliden intrusion. Microphotograph. (l) Chlorite porphyroblasts with an internal (Sc) foliation occurring at a high angle towards the external main foliation (S2). Microphotograph; approximately horizontal section, north upwards. (m) Isoclinal F2-folds deforming the weak older foliation in altered metavolcanic rocks, both overprinted by open NW-SE striking D2L crenulations. Microphotograph, sub-horizontal view, north upwards. Width of view $11 \mathrm{~mm}$. (n) Close-up of (m) displaying folding of the oldest generation of foliation (Sc) around the F2 fold hinge. Width of view approximately $2 \mathrm{~mm}$. 

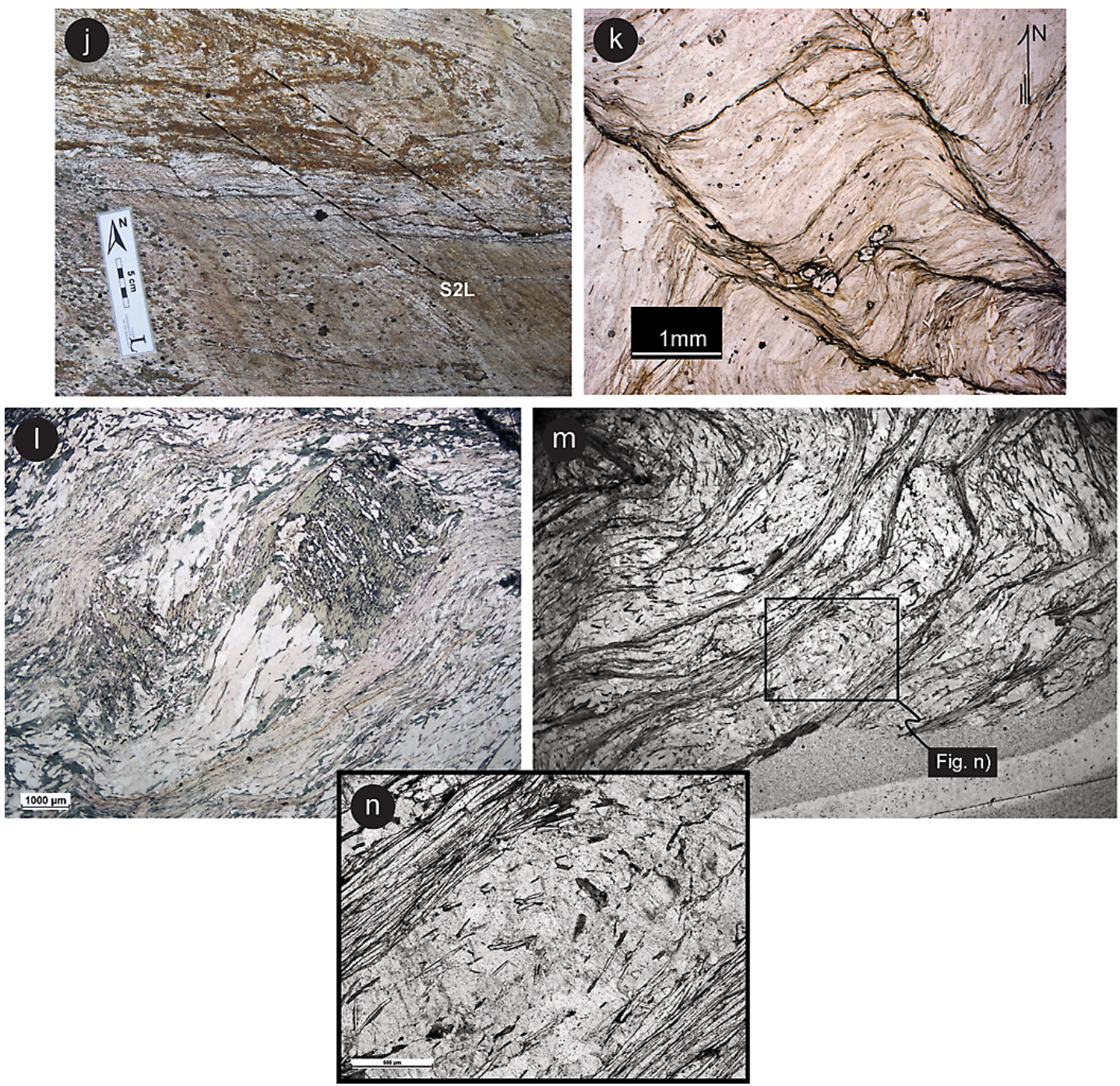

Fig. 7. Continued

regime, there must be a significant strain gradient with increasing dip-slip displacement from west to east along the high-strain zone "II" in Fig. 2a. Analogous to the Southern antiform, the plunging nature of the Northern antiform may be attributed to uplift in the east. Since the Northern antiform exposes a shallower cut through the crust, as shown by the limited area of exposed Skellefte Group metavolcanic rocks within its core, an apparently smaller amount of uplift relative to the Southern antiform was required. This is in line with the general trend of decreasing strain and metamorphic grade from south to north across the Skellefte district (Kathol and Weihed, 2005; Skyttä et al., 2012). The westerly dip of the Rökå mineralization east of the Viterliden intrusion suggests that the whole Kristineberg area may have experienced tilting towards the west, here attributed to dip-slip movements along the Deppis-Näsliden shear zone in the east (Fig. 1).

\section{Modelling}

\subsection{The modelling volume, units and workflow}

The model covers laterally the $21 \mathrm{~km} \times 36 \mathrm{~km}$ area shown in Fig. 2a and extends vertically approximately $4 \mathrm{~km}$ above and $8 \mathrm{~km}$ below the present erosion level (Fig. 10a; Supplement). The top/bottom contacts of the following geological units have been modelled as 3-D surfaces: the early-orogenic Viterliden intrusion, the contact between the Skellefte Group metavolcanic rocks and Vargfors Group metasedimentary rocks, mafic sills within the Vargfors Group rocks and lateto post-orogenic intrusive rocks. Structural features included in the model are bedding form surfaces within the Vargfors Group rocks to illustrate the structural geometry, axial surfaces of major folds, and high-strain zones. The variation in the attitude of mineral lineations is shown by 3-D arrows each of which represents the dominant orientation of 


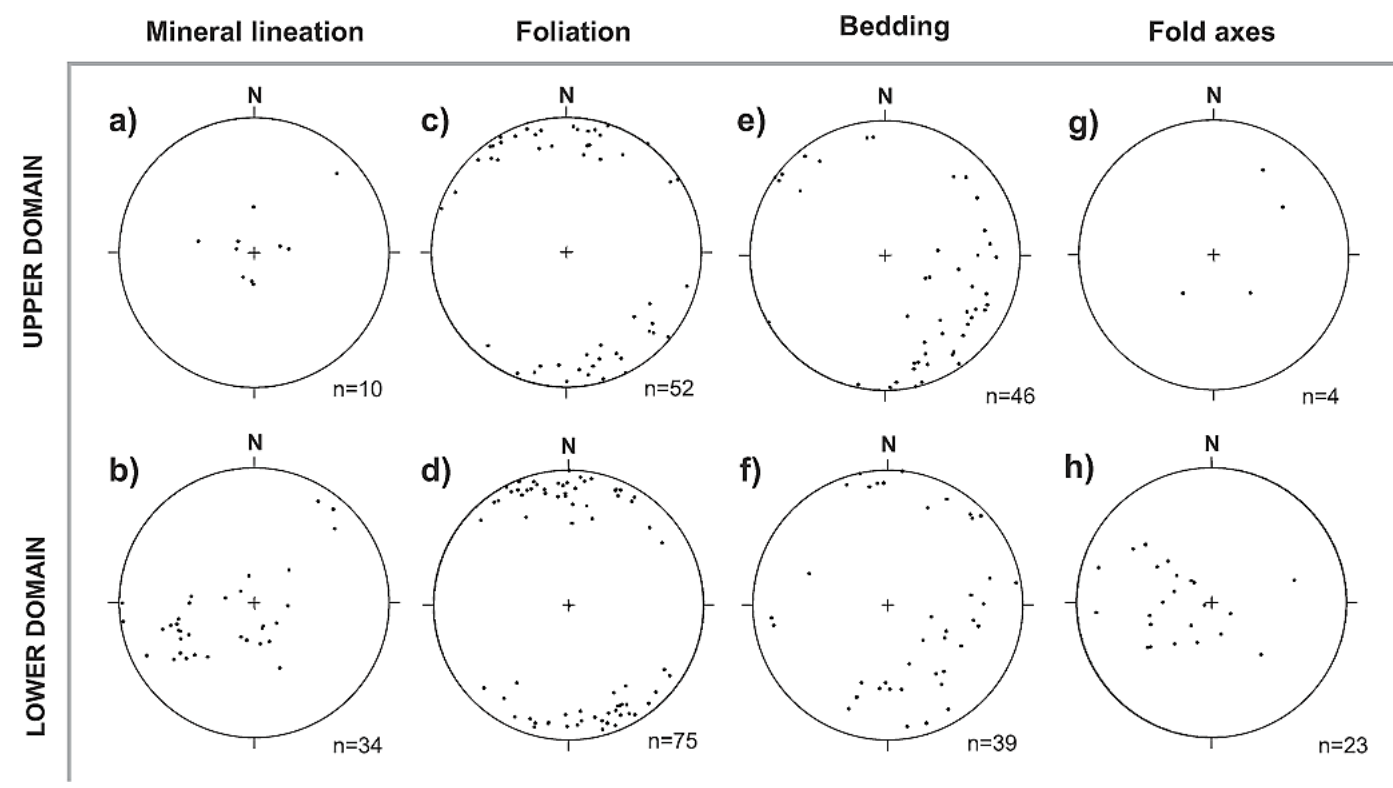

Fig. 8. Lower hemisphere, equal-area stereographic projections of main structural elements in the Kristineberg area. The structural planes in $(\mathbf{c}, \mathbf{d})$ and $(\mathbf{e}, \mathbf{f})$ are visualized as poles to the respective planes. The upper and lower crustal domains occur to the north and south of the high-strain zone "II" in Fig. 2a, respectively.

the observed outcrop or group of outcrops. The 3-D model is provided as a 3-D PDF file in the Supplement, including a legend and a brief guide helping to explore the model.

Ore lenses from the Kristineberg, Rävliden and Rävlidsmyran deposits were imported into the model as surface sets from the Boliden Mineral AB database. Line intersections of the preliminary geological surfaces along three parallel cross sections (Fig. 2a) were collected and "cleaned" to get seamless line intersections with $\mathrm{MOVE}^{\mathrm{TM}}$ software. Compilation of the final 3-D surfaces and export into 3-D PDF format (Supplement) was performed by gOcad with the Sparse plug-in.

\subsection{Constraints on the 3-D shape of the modelled units from structural geology and regional-scale geophysics}

The contact between the Skellefte Group (SG) and Vargfors Group (VG) could be fairly well constrained both by seismic reflection studies (Fig. 4c; Dehghabńnejad et al., 2010, 2012b) and drillings along the cross section shown in Fig. 5a (Boliden Mineral AB). From this location, the SG-VG contact was extrapolated towards east and west using the apparent dips retrieved from the seismically constrained structural long-section running across the Southern antiform (Figs. 5c, $10 \mathrm{~b})$. The recognized transpressional geometry with alternating steep and flat domains was applied when modelling the top contact of the Viterliden intrusion, the SG-VG contact, and structural form surfaces within the Vargfors Group. From the westerly dip of the Rökå mineralization (Fig. 2a), the eastern contact of the Viterliden intrusion was inferred to dip west. The northern contact of the Viterliden intrusion is inferred to be sub-vertical, analogous to the overturned northern flank of the Southern antiform. The orientation of resistor "RII" by García Juanatey et al. (2013) infers that the E-W "nose" of the intrusion immediately north of the Kristineberg deposit has a moderate to steep westerly plunge (Supplement). The southern intrusion contact is drawn arbitrarily since no data from the area was available.

The Northern antiform was inferred to have a gentle and rather uniform plunge towards south-west until the hinge transects the present erosion level. Further west, field data indicate steeper plunges. The folds within the metavolcanic units are inferred to be upright and approximately symmetric, whereas within the metasedimentary units to the northwest they are asymmetric (Fig. 10c). This infers that strain was preferentially partitioned into the metasedimentary rocks and into the high-strain zone separating the metavolcanic and metasedimentary rocks (Bauer et al., 2011). The depth of the SG-VG contact north-west of the Northern antiform is not known and was consequently drawn arbitrarily. For this reason, the difference in the depth of this contact across the transfer faults (Supplement) is illustrative only.

The high-strain zone pattern along the surface has been interpreted from known occurrences along the geological cross sections (Fig. 5a, b) and from magnetic data. The latter indicates that the majority of the high-strain zones terminate against the west-dipping SG-VG contact or against mafic sills hosted by the Vargfors Group metasedimentary rocks (Fig. 2a). The in-depth continuation of the high-strain zones has been interpreted from available MT and seismic data 
(Sect. 2). We interpreted the major north-dipping reflector largely underlying the whole modelling area (Fig. 8e; Tryggvason et al., 2006; Hübert et al., 2009; García Juanatey et al., 2013) as a north-dipping shear zone which flattens and deflects into a more $\mathrm{N}-\mathrm{S}$ strike towards the east. Consequently, the geometry of the zone is in good agreement with the sigmoidal pattern of high-strain zone traces within the Viterliden intrusion (Skyttä et al., 2010), but also with the attitude of seismic reflectors observed below or within the intrusion ("W1" and "D1" in Dehghannejad et al., 2010). Considering the northerly dip of the crustal reflector in Tryggvason et al. (2006), the largest high-strain zones bounding the southern margin of the Southern antiform are inferred to have northerly dips. Analogous to the northerly dip of the above high-strain zones, the E-W striking shear zone at "I" was also considered to dip towards the north (Figs. 2a, 10c). As a consequence of the contrasting northerly high-strain zone dips at the depth and the southerly dips higher-up in the crust, we interpret the south-dipping structures within the uppermost $2 \mathrm{~km}$ as antithetic structures with respect to the major north-dipping high-strain zone.

The presence of high-strain zones with opposing dip directions is in good agreement with the box-fold geometry of the Southern antiform (Fig. 2a). The greatest uncertainty among the modelled high-strain zones is with "II" in Figs. 2 and 10c. The seismic signal in this location is generally weak (Tryggvason et al., 2006) and the MT data may equally well be fitted with northerly or southerly dips. Since the seismic signatures along the SG-VG contact $2 \mathrm{~km}$ south of "II" have southerly dips (Dehghannejad et al., 2010) and the primary sedimentary contact at " $\mathrm{V}$ " has a moderate southerly dip, we infer that the major high-strain zone at "II" also has a southerly dip. According to MT data (Fig. 4e) the SG-VG contact between the Northern and Southern antiforms may be inferred to be present at a depth of around $1500 \mathrm{~m}$. However, due to the uncertainties in constraining the high-strain zone "II" it is impossible to reliably define the 3-D shape of the contact. The SE-NW striking transfer faults in the NW part of the modelling area are inferred from the structural trends along the surface and drawn vertically.

The moderate to steep southerly dip of the contact of the late- to post-orogenic granite south of the Southern antiform has been constrained by the transparent seismic signature in the S-part of the seismic profiles (Tryggvason et al., 2006). This is also in line with the MT data (Hübert et al., 2009; García Juanatey et al., 2013). Consequently, we drew the contact of the granite surrounding the Kristineberg antiform as a steeply outwards-dipping surface down to approximately $4 \mathrm{~km}$ depth. In contrast, the oval-shaped late- to post-orogenic intrusion transecting the Northern antiform is a sheet-like intrusion with a maximum depth of 600-700 m (Malehmir et al., 2007).

\section{Discussion}

\subsection{3-D crustal scale geometry}

The variably striking high-strain zones "I" and "II" (Fig. 2a) may be attributed to splaying of high-strain along their termination: zone "I" is the western continuation of the major ESE-WNW striking high-strain zone separating the coaxial and non-coaxial crustal domains further east (Skyttä et al., 2012). Zone "II" is a splay of zone "I" and separates the Northern and Southern antiforms (Fig. 2a). The inferred termination of the major high-strain zone north of the Kristineberg area would also very nicely explain the termination of the high-strain zones within the Southern antiform. Furthermore, we attribute the formation of splays responsible for the generation of major plunging antiformal structures in the Kristineberg area, a feature distinctly contrasting to the central parts of the district characterized by sub-horizontal fold hinges (Bauer et al., 2011; Skyttä et al., 2012). The crustal depth within the transpressive domain of Kristineberg is apparently smaller compared with e.g. the Holmträsk domain of Skyttä et al. (2012) since no tectonic S1 foliations characteristic for the non-coaxial, deeper crustal domain may be found in Kristineberg. Nevertheless, the tendency towards more flat-lying lineations with increasing depth is common for both the Kristineberg area (Fig. 8a, b) and the central Skellefte district.

Considering the timing of deformation events, the suggested splaying of a major fault is in favour of the model comprising of one SSE-NNW transpressive event at around $1.87 \mathrm{Ga}$ rather than two separate events with contrasting bulk compression orientations (Skyttä et al., 2012). Furthermore, the previously observed dextral strike-slip overprint on the dip-slip deformation within the Viterliden intrusion (Skyttä et al., 2010) may now be attributed to progressive SSE-NNW transpression. Recognition of the SSE-NNW transpressional deformational regime and, in specific, the characteristic partitioning between the areas of $\mathrm{N}-\mathrm{S}$ and $\mathrm{E}-\mathrm{W}$ compression during D2 suggests that the E-W crustal shortening at around $1.8 \mathrm{Ga}$ (D3 by Bergman Weihed 2001) was probably due to a new period of SSE-NNW transpression and not a completely new event with a contrasting $\mathrm{E}-\mathrm{W}$ regional shortening direction.

In district-scale, the northerly dip for the main reflectors within the Kristineberg area (Tryggvason et al., 2006) is contrasting to the southerly dips of reflectors from the central parts of the district (Dehghannejad et al., 2012a). For this reason, we infer that the formation of crustal compartments with opposite polarities previously recognized at a rather local scale (Bauer et al., 2011) may be attributed to the whole district. Consequently, the dip of the major crustal features is inferred to change across the approximately N-S striking Deppis-Näsliden shear zone and Vidsel-Röjnöret shear system (Fig. 1) and possibly also along some of the smaller-scale N-S striking transfer zones (Skyttä et al., 2012). 

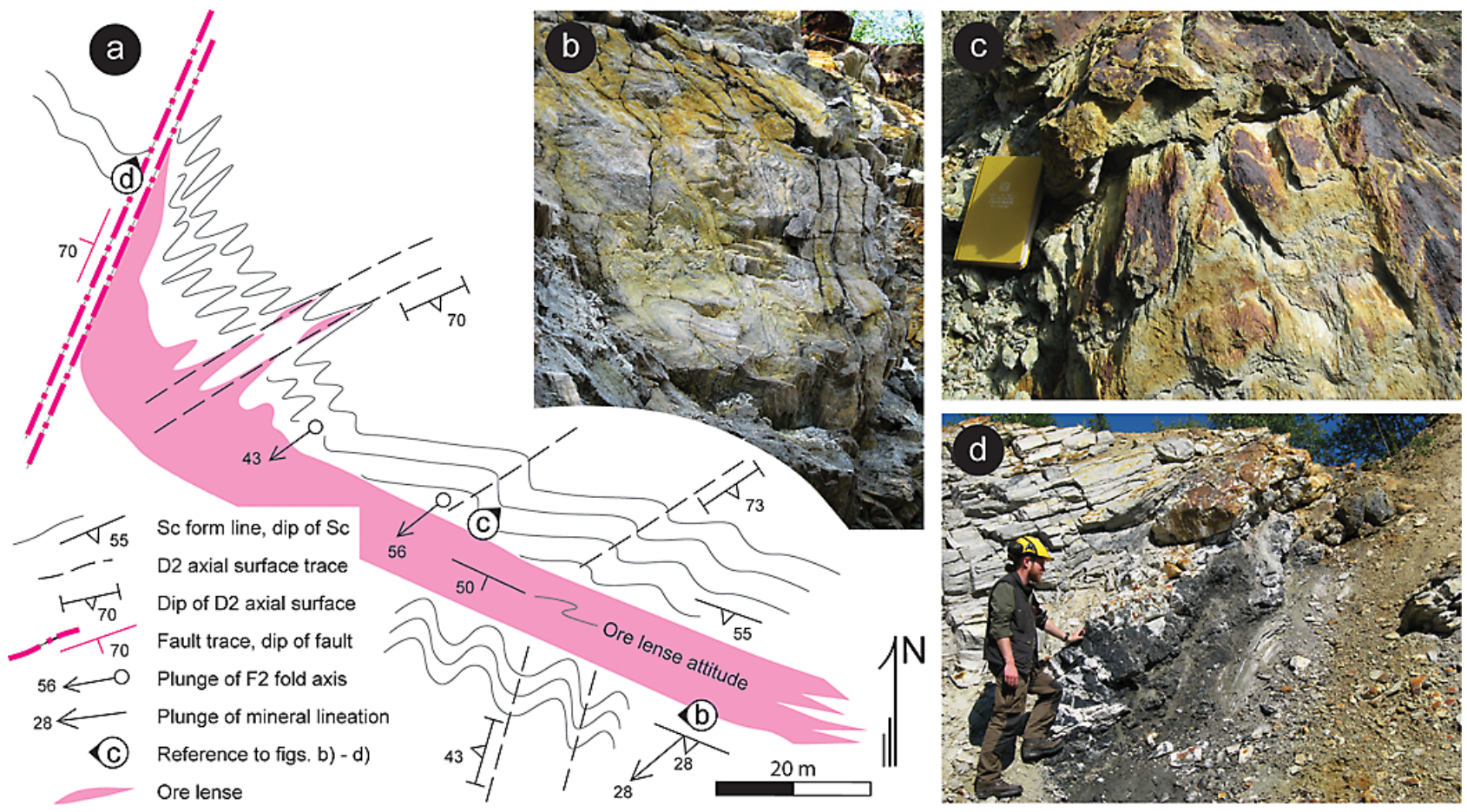

Fig. 9. Structures in the A4 open pit, see Fig. 2a for location. (a) Geological overview of the A4 open pit. (b) Plunging inclined F2 folds in the sericite-altered stratigraphic hanging wall to the A4 ore lens. Vertical section, view towards W. Width of view approximately 2 m. (c) Plunging upright F2 folds in the stockwork-system mineralization in the stratigraphic footwall to the A4 ore lens. View up-plunge along the fold axes, towards NE. Width of view approximately $80 \mathrm{~cm}$. (d) A semi-brittle WNW-dipping high-strain zone constraining the western extent of the A4 ore lens. Vertical section, view towards NNE.

\subsection{Deformation and the ore deposit geometry}

Adjustments to the original form and orientation of the VMS deposits may have taken place either by tectonic transposition or syntectonic remobilization, or by a combination of these. Remobilization of VMS ore should lead to the transport of ore into extensional sites, e.g. within releasing bends of the high-strain zones. Consequently, the attitude of at least some of the ore lenses should deviate from the local tectonic transport direction as indicated by the mineral lineations. An example of ore remobilization is known from the Kristineberg deposit K lens (Fig. 11a, b; Årebäck et al., 2005) where the longest axis of the ore lens is orthogonal to the local S-side-up reverse displacements along the shear zones. However, the K-lens geometry resembles that of the adjoining lenses which have not experienced remobilization and, therefore, the remobilization has originally not been recognized by the structural signature but by other methods (Årebäck et al., 2005). In the scale of the whole Skellefte district, the large majority of VMS deposits show nearly perfect parallelism between their longest axes and the surrounding pattern of systematically oriented mineral lineations (Skyttä et al., 2012; Bauer et al., 2013). For this reason, the role of remobilization in reorienting the ore deposits has to be considered insignificant. Consequently, the present-day geome- try of the deposits is here attributed to both their syngenetic shape and tectonic strain and transposition.

Folding is the main controlling factor over the geometry of the Kristineberg deposits, as illustrated by the occurrence of the largest ore lenses (A and B) as steeply south-dipping bodies on the limb of a synformal structure, and bending of the deeper parts of the ore (e.g. $L$ zone) into gentler dips towards the hinge of the fold in the south (Fig. 11a-c). The ore lenses in the deep parts of the deposit define an overall elongate, sub-horizontal to gently west-plunging domain, which is due to the splitting up of the originally horizontal and continuous ore sheets into smaller slices during the main deformation. The recognized SE-NW transpression suggests that the approximately E-W, south-dipping reverse shear zones had an additional dextral strike-slip component, which is in line with the apparent deflection of the deeper parts of the deposit (Fig. 3). The Rävliden and Rävmyrliden ore lenses occur immediately below the Vargfors-Skellefte Group contact, and their westerly plunges are inferred to reflect an overall tilting of the strata towards the west, coupled with the more localized transposition into sub-vertical dips along the reverse shear zones (Fig. 11d).

At a local-scale, the observations from the A4 open pit show that zones of pronounced folding could be significant in transposing the ore into variable strikes at the scale of 

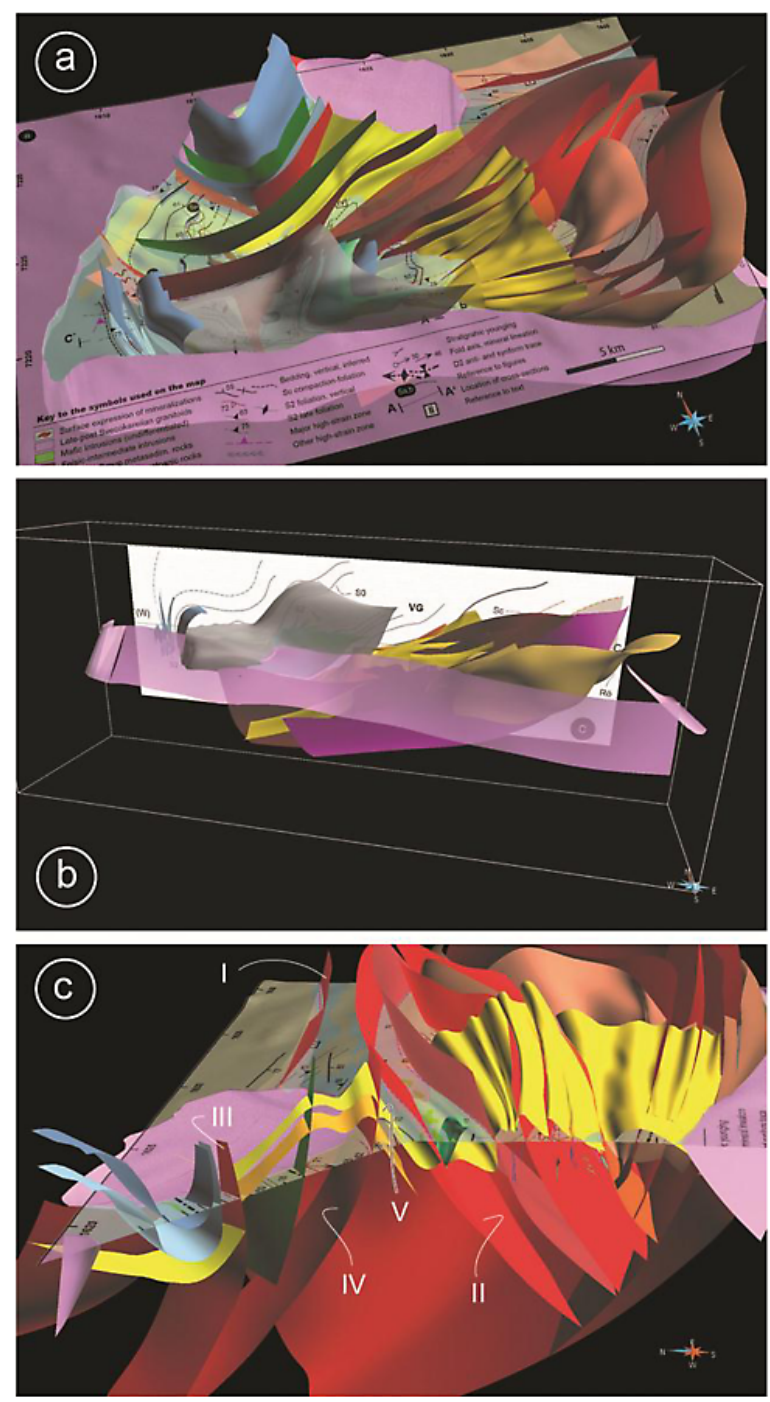

Fig. 10. gOcad screenshots of the 3-D model over the Kristineberg area, see Supplement for the related 3-D PDF file. (a) An overview of the model, an oblique view towards NNE. (b) A long-sectional view highlighting the variable geometry along the hinge of the Southern antiform. (c) A sliced view with reference to locations "I"-"V" discussed in the text (see Fig. 2a for locations).

individual ore lenses or sets of lenses (Fig. 9a). Furthermore, change in the F2 fold geometry from the stratigraphical footwall to the hanging wall implies that substantial deformation was localized either within the ore sheet or along its contacts. Since the axes of the folds on both sides of the ore sheet are parallel with each another, and with the observed mineral lineation, but vary in the axial surface orientation, we infer that the contrasting fold geometries are due to strike-slip dominated shear with a smaller reverse dip-slip component along the WNW-ESE high-strain zone. This interpretation is in line with dextral strike-slip deformation observed along an ENE-WSW high-strain zone within the Viterliden intrusion,
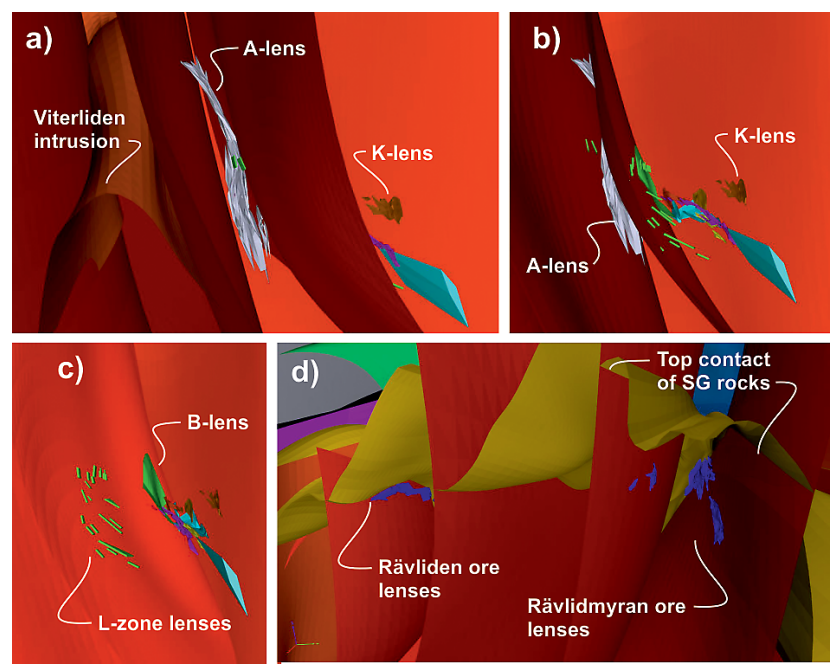

Fig. 11. Screenshots from the Supplementary 3-D PDF illustrating the geometry of the Kristineberg area VMS deposits. The surfaces in various shades of red are shear zones. (a-c) show the Kristineberg deposit viewed towards approximately $\mathrm{E}$, with slight rotation from a view towards ESE in (a) towards ENE in (c). (d) Rävliden and Rävlidmyran deposits viewed towards WSW. The grey, green and blue are structural form surfaces (see Supplement for details).

directly east of the A4 open pit (Fig. 2a; Skyttä et al., 2010). Of significance for the local-scale continuation of the ore are also those high-strain zones which occur at high angles to the strike of the deposits and may define the lateral extent of individual ore bodies (Fig. 9a, d).

Summing up, reverse movements along the south-dipping shear zones and the related folding have the strongest control over the present-day orientation and form of the ore deposits and their individual ore lenses. However, the evidence for (dextral) strike-slip shearing suggests that the previously inferred lateral flow could be locally significant in reorienting the ore lenses (Skyttä et al., 2009). The more complex structural geometry of the stratigraphically deeper deposits (Kristineberg) further suggests that the role of sub-horizontal tectonic movements increases with increasing crustal depth. For this reason, the transposition of the Kristineberg ore deposits is perfectly in line with the regional structural transitions characterized by localized coaxial deformation and sub-vertical lineations at high crustal levels, and more penetrative, sub-horizontal flow deeper in the crust (Skyttä et al., 2012).

\section{Conclusions}

The crustal structure of the Kristineberg area may be attributed to SSE-NNW transpression which may be correlated with the formation of the characteristic upright folds in the central Skellefte district at around $1.87 \mathrm{Ga}$. 
Formation of splays at the western termination of a major ESE-WNW high-strain zone (during the transpression) is attributed as responsible for the development of two major antiformal structures: the coaxial, upper crustal Northern antiform and the transpressional, deeper crustal Southern antiform.

The complex geometry of the Southern antiform is explained by deformation partitioning during the transpression, when the $\mathrm{N}-\mathrm{S}$ component of compression led to reverse shearing along the approximately E-W striking shear zones and the E-W component of compression affected the lowstrain domains in-between, leading to localized and progressive tilting of strata into steeper west-dipping to overturned attitudes. Dextral strike-slip deformation along the approximately E-W high-strain zones is attributed to the progressive SSE-NNW transpression.

The present-day geometry of the complex VMS deposits in the Kristineberg area may be attributed to tectonic transposition dominantly controlled by reverse shearing and related folding, with increasing influence of sub-horizontal tectonic movements with increasing crustal depth.

The crustal-scale, 3-D structure could be constrained by the integration of magnetotelluric, seismic reflection and structural data into a semi-regional-scale 3-D model. The major crustal feature within the Kristineberg area is the north-dipping reflector which we attribute to the formation of crustal compartments with opposite polarities within the scale of the whole Skellefte district

\section{Supplementary material related to this article is available online at http://www.solid-earth.net/4/387/ 2013/se-4-387-2013-supplement.pdf.}

Acknowledgements. We would like to thank journal editor Federico Rossetti, reviewers Adrea Brogi, Gianluca Vignaroli and one anonymous person for comments on the manuscript. We acknowledge Midland Valley Exploration Ltd. for the use of MOVE $^{\mathrm{TM}}$ software under the Academic Software Initiative (ASI). This work is part of the VINNOVA 4-D modelling of the Skellefte district, funded by VINNOVA and Boliden Mineral AB, and the PROMINE project partially funded by the European Commission under the 7th Framework Programme.

Edited by: F. Rossetti

\section{References}

Allen, R. L., Weihed, P., and Svenson, S.-Å.: Setting of Zn-Cu-AuAg massive sulfide deposits in the evolution and facies architecture of a 1.9 Ga marine volcanic arc, Skellefte District, Sweden, Econ. Geol., 91, 1022-1053, 1996.
Årebäck, H., Barrett, T. J., Abrahamsson, S., and Fagerström, P.: The Palaeoproterozoic Kristineberg VMS deposit, Skellefte District, northern Sweden, part I: geology, Miner Deposita, 40, 351367, 2005.

Bauer, T. E., Skyttä, P., Allen, R. L., and Weihed, P.: Synextensional faulting controlling structural inversion - Insights from the Palaeoproterozoic Vargfors syncline, Skellefte mining district, Sweden, Precambrian Res., 191, 166-183, 2011.

Bauer, T. E., Skyttä, P., and Hermansson, T.: Correlation between distribution and shape of VMS deposits, and regional deformation patterns, Skellefte district, northern Sweden, Miner Deposita, in review, 2013.

Bergman Weihed, J.: Palaeoproterozoic deformation zones in the Skellefte and the Arvidsjaur areas, northern Sweden, in: Economic Geology Research 1, edited by: Weihed, P., Sveriges Geologiska Undersökning, C 833, 46-68, 2001.

Billström, K. and Weihed., P.: Age and provenance of host rocks and ores of the Palaeoproterozoic Skellefte District, northern Sweden, Econ. Geol., 91, 1054-1072, 1996.

Dehghannejad, M., Juhlin, C., Malehmir, A., Skyttä, P., and Weihed, P.: Reflection seismic imaging of the upper crust in the Kristineberg mining area, northern Sweden, J. Appl. Geophys., 71, 125-136, 2010.

Dehghannejad, M., Bauer, T. E., Malehmir, A., Juhlin, C., and Weihed, P.: Crustal geometry of the central Skellefte district, northern Sweden - constraints from reflection seismic investigations, Tectonophysics, 20, 87-99, 2012a.

Dehghannejad, M., Malehmir, A., Juhlin, C., and Skyttä, P.: 3D constraints and finite-difference modeling of massive sulfide deposits: The Kristineberg seismic lines revisited, northern Sweden, Geophysics, 77, WC69-WC79, 2012b.

Ehsan, S. A., Malehmir, A., and Dehghannejad, M.: Re-processing and intepretation of 2D seismic data from the Kristineberg mining area, northern Sweden, J. Appl. Geophys., 80, 43-55, 2012.

Gaál, G.: Tectonic styles of early Proterozoic ore deposition in the Fennoscandian shield, Precambrian Res., 46, 83-114, 1990.

Galley, A. G. and Bailes, A. H.: The interrelationship between the Viterliden intrusion, synvolcanic alteration, and volcanogenic massive sulphide mineralization, Kristineberg region, Skellefte District, Sweden, CAMIRO, Project 94E07, Draft technical report (unpublished), 71 pp., 1999.

García Juanatey, M., Hübert, J., Tryggvason, A., and Pedersen, L.: Imaging the Kristineberg mining area with two perpendicular magnetotelluric profiles in the Skellefte Ore District, northern Sweden, Geophys. Prospecting, 61, 200-219, 2013.

Gonzàlez-Roldán, M. J.: Mineralogia, petrologia y geocuimica de intrusions sin-volcanicas en el distrito minero de Skellefte, norte Suecia, unpublished Ph.D. thesis (in Spanish with English summary), University of Huelva, Spain, 273 pp., 2010.

Hietanen, A.: Generation of potassium-poor magmas in the northern Sierra Nevada and the Svecofennian of Finland, J. Res. US Geol. Surv., 3, 631-645, 1975.

Hübert, J., Malehmir, A., Smirnow, M., Tryggvason, A., and Pedersen, L. B.: MT measurements in the western part of the Paleoproterozoic Skellefte Ore District, Northern Sweden: A contribution to an intergrated geophysical study, Tectonophysics, 475, 493$502,2009$.

Hübert, J., García Juanatey, M. A., Malehmir, A., Tryggvason, A., and Pedersen, L. B.: The upper crustal 3-D resistivity structure 
of the Kristineberg area, Skellefte district, northern Sweden revealed by magnetotelluric data, Geophys. J Int., 192, 500-513, 2013.

Jolley, S.: Structural controls on sulphide remobilisation and deformation: Kristineberg gold mine, Unpublished report 2057 (for Boliden Mineral AB), Rock Deformation Research Group, 37 pp., 2001.

Juhlin, C., Elming, S.-Å., Mellqvist, C., Öhlander, B., Weihed, P., and Wikström, A.: Crustal reflectivity near the ArchaeanProterozoic boundary in northern Sweden and implications for the tectonic evolution of the area, Geophys. J Int., 150, 180-197, 2002.

Kathol, B. and Weihed, P. (Eds.): Description of regional geological and geophysical maps of the Skellefte District and surrounding areas, Sveriges Geologiska Undersökning, Ba 57, 197 pp., 2005.

Kathol, B., Weihed, P., Antal Lundin, I., Bark, G., Bergman Weihed, J., Bergström, U., Billström, K., Björk, L., Claesson, L., Daniels, J., Eliasson, T., Frumerie, M., Kero, L., Kumpulainen, R. A., Lundström, H., Lundström, I., Mellqvist, C., Petersson, J., Skiöld, T., Sträng, T., Stølen, L.-K., Söderman, J., Triumf, C.-A., Wikström, A., Wikström, T., and Årebäck, H.: Regional geological and geophysical maps of the Skellefte district and surrounding areas, Bedrock map, Sveriges geologiska undersökning, Ba 57:1, 2005.

Lickorish, H.: Structural profiles through the Skellefte Belt, northern Sweden, Unpublished report for Georange, 38 pp., 2005.

Lundström, I. and Antal, I.: Bedrock map 23K Boliden, scale 1:50 000, Sveriges Geologiska Undersökning, Ai 110-113, 2000.

Lundström, I., Vaasjoki, M., Bergström, U., Antal, I., and Strandman, F.: Radiometric age determinations of plutonic rocks in the Boliden area: the Hobergsliden granite and the Stavaträsk diorite, in: Radiometric dating results 3, edited by: Lundqvist, T., Sveriges Geologiska Undersökning, C 830, 20-30, 1997.

Lundström, I., Persson, P.-O., and Bergström, U.: Indications of early deformational events in the north-eastern part of the Skellefte field. Indirect evidence from geological and radiometric data from the Stavaträsk-Klintån area, Boliden map-sheet, in: Radiometric dating results 4, edited by: Bergman, S., Sveriges geologiska undersökning, C 831, 52-69, 1999.

Malehmir, A., Tryggvason, A., Lickorish, H., and Weihed, P.: Regional structural profiles in the western part of the Palaeoproterozoic Skellefte ore district, northern Sweden, Precambrian Res., 159, 1-18, 2007.

Malehmir, A., Thunehed, H., and Tryggvason, A.: The Paleoproterozoic Kristineberg mining area, northern Sweden: Results from integrated 3D geophysical and geologic modelling, and implications for targeting ore deposits, Geophysics, 74, B9-B22, 2009a.

Malehmir, A., Schmelzbach, C., Bongajum, E., Bellefleur, G., Juhlin, C., and Tryggvason, A.: 3D constraints on a possible deep $>2.5 \mathrm{~km}$ massive sulphide mineralization from 2D crooked-line seismic reflection data in the Kristineberg mining area, northern Sweden, Tectonophysics, 479, 223-240, 2009 b.
Montelius, C.: The genetic relationship between rhyolitic volcanism and $\mathrm{Zn}-\mathrm{Cu}-\mathrm{Au}$ deposits in the Maurliden Volcanic Centre, Skellefte District, Sweden: volcanic facies, lithogeochemistry and geochronology, Ph.D. thesis, Luleå University of Technology, Sweden, 15 pp., 2005.

Petersen, S., Herzig, P. M., and Hannington, M.: Third dimension of a presently forming VMS deposit: TAG hydrothermal mound, Mid-Atlantic Ridge $26^{\circ}$ N. Miner. Deposita, 35, 233-259, 2009.

Rutland, R. W. R., Kero, L., Nilsson, G., and Stølen, L. K.: Nature of a major tectonic discontinuity in the Svecofennian province of northern Sweden, Precambrian Res., 112, 211-237, 2001a.

Rutland, R. W. R, Skiöld, T., and Page, R. W.: Age of deformation episodes in the Palaeoproterozoic domain of northern Sweden, and evidence for a pre-1.9 Ga crustal layer, Precambrian Res., 112, 239-259, 2001b.

Skiöld, T. Öhlander, B., Markkula, H., Widenfalk, L., and Claesson, L. A.: Chronology of Proterozoic orogenic processes at the Archaean continental margin in northern Sweden, Precambrian Res., 64, 225-238, 1993.

Skyttä, P., Hermansson, T., and Bauer, T.: Three Dimensional Structure of the VMS-hosting Palaeoproterozoic Kristineberg Area, Northern Sweden, Proceedings of the 10th biennial SGA meeting, Townsville, Australia, 909-911, 2009.

Skyttä, P., Hermansson, T., Elming, S.-̊̊ ., and Bauer, T.: Magnetic fabrics as constraints on the kinematic history of a pretectonic granitoid intrusion, Kristineberg, northern Sweden, J. Struct. Geol., 32, 1125-1136, 2010.

Skyttä, P., Hermansson, T., Andersson, J., Whitehouse, M., and Weihed, P.: New zircon data supporting models of short-lived igneous activity at $1.89 \mathrm{Ga}$ in the western Skellefte District, central Fennoscandian Shield, Solid Earth, 2, 205-217, doi:10.5194/se2-205-2011, 2011

Skyttä, P., Bauer, T., Tavakoli, S., Hermansson, T., Andersson, J., and Weihed, P.: Pre-1.87 Ga development of crustal domains overprinted by $1.87 \mathrm{Ga}$ transpression in the Palaeoproterozoic Skellefte district, Sweden, Precambrian Res., 206-207, 109-136, 2012.

Tryggvason, A., Malehmir, A., Rodriguez-Tablante, J., and Juhlin, C.: Reflection seismic Investigations in the Western Part of the Paleoproterozoic VHMS- Bearing Skellefte District, Northern Sweden, Econ. Geol., 101, 1039-1054, 2006.

Weihed, P., Billström, K., Persson, P.-O., and Bergman Weihed, J.: Relationship between $1.90-1.85$ Ga accretionary processes and 1.82-1.80 Ga oblique subduction at the Karelian craton margin, Fennoscandian Shield, GFF, 124, 163-180, 2002.

Yakubchuk, A.: Architecture and mineral deposit settings of the Altaid orogenic collage: a revised model, J. Asian Earth Sci., 23, 761-779, 2004. 